\title{
The Role of Antibiotic Resistant A. baumannii in the Pathogenesis of Urinary Tract Infection and the Potential of Its Treatment with the Use of Bacteriophage Therapy
}

\author{
Natalia Bagińska ${ }^{1}$, Martyna Cieślik ${ }^{1}(\mathbb{D}$, Andrzej Górski 1,2,3® and Ewa Jończyk-Matysiak 1,* \\ 1 Bacteriophage Laboratory, Hirszfeld Institute of Immunology and Experimental Therapy, \\ Polish Academy of Sciences, 53-114 Wrocław, Poland; natalia.baginska@hirszfeld.pl (N.B.); \\ martyna.cieslik@hirszfeld.pl (M.C.); agorski@ikp.pl (A.G.) \\ 2 Phage Therapy Unit, Hirszfeld Institute of Immunology and Experimental Therapy, \\ Polish Academy of Sciences, 53-114 Wrocław, Poland \\ 3 Infant Jesus Hospital, The Medical University of Warsaw, 02-006 Warsaw, Poland \\ * Correspondence: ewa.jonczyk-matysiak@hirszfeld.pl; Tel.: +48-71-3709968
}

check for updates

Citation: Bagińska, N.; Cieślik, M.; Górski, A.; Jończyk-Matysiak, E. The Role of Antibiotic Resistant $A$. baumannii in the Pathogenesis of Urinary Tract Infection and the Potential of Its Treatment with the Use of Bacteriophage Therapy. Antibiotics 2021, 10, 281. https:// doi.org/10.3390/antibiotics10030281

Academic Editor: Carla Pereira

Received: 5 February 2021

Accepted: 5 March 2021

Published: 9 March 2021

Publisher's Note: MDPI stays neutral with regard to jurisdictional claims in published maps and institutional affiliations.

Copyright: (c) 2021 by the authors. Licensee MDPI, Basel, Switzerland. This article is an open access article distributed under the terms and conditions of the Creative Commons Attribution (CC BY) license (https:// creativecommons.org/licenses/by/ $4.0 /)$.

\begin{abstract}
Acinetobacter baumannii are bacteria that belong to the critical priority group due to their carbapenems and third generation cephalosporins resistance, which are last-chance antibiotics. The growing multi-drug resistance and the ability of these bacteria to form biofilms makes it difficult to treat infections caused by this species, which often affects people with immunodeficiency or intensive care unit patients. In addition, most of the infections are associated with catheterization of patients. These bacteria are causative agents, inter alia, of urinary tract infections (UTI) which can cause serious medical and social problems, because of treatment difficulties as well as the possibility of recurrence and thus severely decrease patients' quality of life. Therefore, a promising alternative to standard antibiotic therapy can be bacteriophage therapy, which will generate lower costs and will be safer for the treated patients and has real potential to be much more effective. The aim of the review is to outline the important role of drug-resistant $A$. baumannii in the pathogenesis of UTI and highlight the potential for fighting these infections with bacteriophage therapy. Further studies on the use of bacteriophages in the treatment of UTIs in animal models may lead to the use of bacteriophage therapy in human urinary tract infections caused by A. baumannii in the future.
\end{abstract}

Keywords: bacteriophages; multidrug resistance (MDR); urinary tract infection (UTI); uropatogenic bacteria; critical priority group

\section{Introduction}

Each year, approximately 150 million people worldwide suffer from UTI [1]. They are caused by uropathogenic bacteria, such as Escherichia coli, Klebsiella, Staphylococcus, Enterococcus [2], and multi-drug resistant (MDR) Acinetobacter baumannii [3]. In addition to bacteria, urogenital infections can be caused by the sub-Saharan Africa endemic parasite Schistosoma haematobium [4] or by Candida species. Fungal infections of the urinary tract caused by Candida affect people with weakened immunity or those who are hospitalized [5]. Infection of the urinary tract causes many difficulties during treatment due to the increasing antibiotic resistance among bacterial strains [6]. Approximately $60 \%$ of women will experience a UTI at least once in their lifetime, and $20-30 \%$ of them will have had a recurrence within 6 months [6-8]. The costs incurred in the fight against UTI are related to the treatment, but also to the loss of productivity related to absence from work [6]. The common method of fighting UTI is antibiotic therapy. A huge problem arose when the widespread use of antibiotics resulted in the appearance of antibiotic-resistant bacterial strains all over the world. Therefore, other possibilities of treatments for UTI should be urgently considered [9]. One of the promising treatment methods is bacteriophage therapy (Figure 1), which can prove to be an effective method of combating this serious medical 
and social problem [10]. The increase in resistance among $A$. baumannii to currently used drugs is shown in Figure 2.

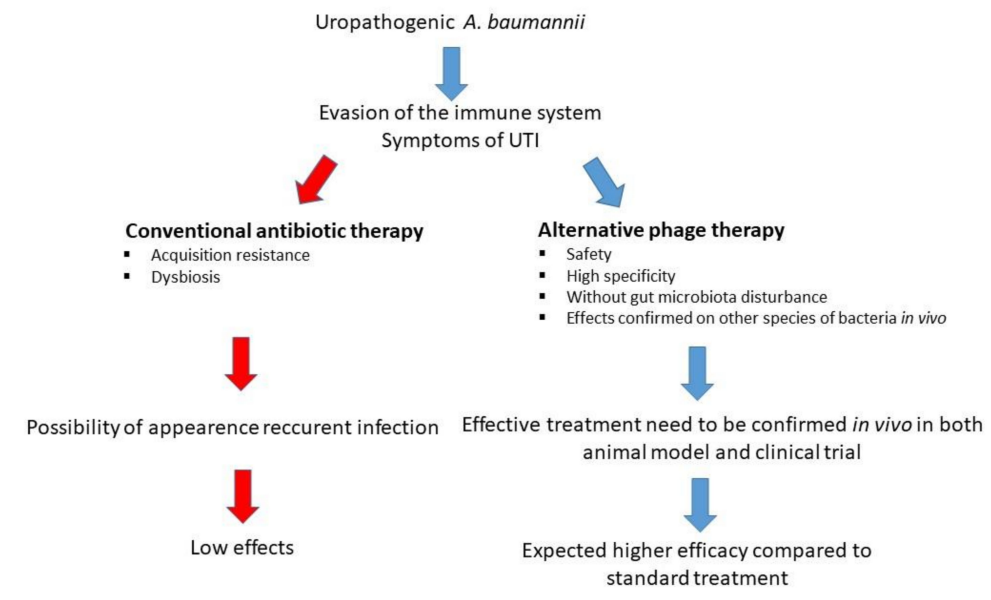

Figure 1. Comparison of antibiotic therapy and the potential new alternative phage therapy in combating uropathogenic strains of A. baumannii.

(A)

2000-2005
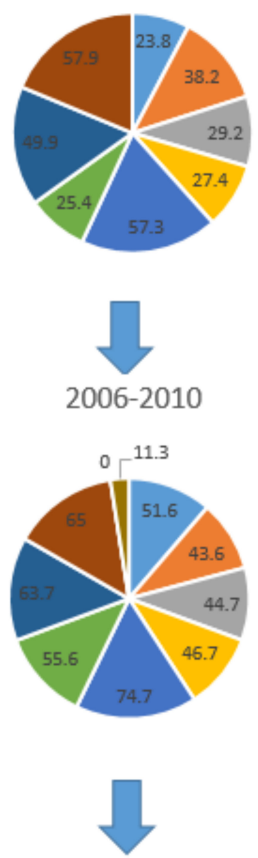

2011-2016

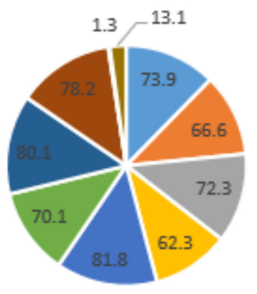

(B) 2006-2010

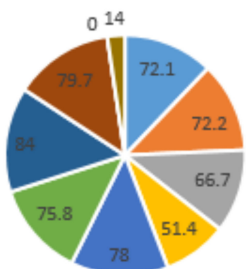

2011-2016

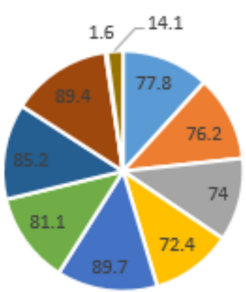

- Imipenem

- Amikacin

- AMP-SUL

- Tobramycin

- Ceftazidime

- Meropenem

- PIP-TAZ

- Cefepime

Figure 2. Resistance of A. baumannii strains in the world to available antibiotics in countries belonging to the Organization for Economic Co-operation and Development (OECD) (A) and non-OECD (B). PIP-TAZ piperacillin-tazobactam, AMP-SUL ampicillin-sulbactam [11]. 
A. baumannii most often causes hospital bacteremia and lung infections. The presence of an endotracheal tube creates an ideal condition for the formation of bacterial biofilm, which results in infection [12]. Bloodstream infections caused by A. baumannii are related to the presence of the central venous catheter or as a consequence of extensive pneumonia. Additionally, A. baumannii causes infections of the urinary tract, usually associated with the presence of percutaneous nephrostomy tubes or urinary catheters. These pathogenic strains are also responsible for meningitis, osteomyelitis, endocarditis and wound infections. These infections occur mainly after an injury or surgery [13-17]. A. baumannii isolates are characterized by multi-drug resistance, therefore the treatment of infections caused by these bacteria is quite limited. Standard treatment of susceptible strains is based on the use of beta lactam antibiotics. In more difficult cases, carbapenems are applied [18-20]. The growing resistance among $A$. baumannii to currently used therapeutics has forced a search for a new effective, as well as safe method of fighting these infections, such as bacteriophage therapy [21]. Bacteriophages can be isolated from various environments [22-24]. Those specific to A. baumannii are most often isolated from water samples, especially from hospital sewage and almost every part of the human body [25-29]. When examining human samples, bacteriophages were detected in 11\% of blood cultures, $14 \%$ of cerebrospinal fluid, $23 \%$ of urine samples, $28 \%$ of serum and $45 \%$ of ascitic fluid [30]. So far, rodent studies have shown that bacteriophages specific to a particular strain of $A$. baumannii can be helpful in combating infection (intraperitoneal sepsis, wound or lung infection) caused by this pathogen [31-34].

\subsection{Global Problem of the Urinary Tract Infections Caused by A. baumannii}

In recent years, all over the world, among nosocomial pathogens, an increasing number of infections have been caused by Gram-negative bacteria. Additionally, many of them are MDR strains [35]. MDR A. baumannii, formerly considered commensals, nowadays are associated with many dangerous hospital infections [36]. These strains can easily be isolated from intubated patients in the intensive care unit (ICU) [37]. Many of these strains are MDR; Lob et al. (2016) in their work described research on A. baumannii strains isolated from patients in 48 countries (453 hospitals) around the world under the Study for Monitoring Antimicrobial Resistance Trends (SMART) [38]. In this study from 2011 and 2014, 2337 A. baumannii isolates were collected. These strains were isolated from patients with intra-abdominal infections and UTIs, and for a group of 1011 isolates (2013-2014), sensitivity and multidrug resistance (resistant to at least three classes of drugs) were determined. Of these, 721 were from patients with intra-abdominal infections and 276 isolates were from patients with UTI. A total of 307 isolates came from intensive care units (ICU), and 615 from other hospital units.

Drug resistance was tested for the isolates of $A$. baumannii. Among the strains causing UTI in the Middle East, over $90 \%$ of the strains were MDR, similar to Europe $90 \%$ of A. baumannii strains were MDR. In Latin America, Africa, Asia and North America, approximately $85 \%, 80 \%, 70 \%$ and $50 \%$ of isolates were MDR, respectively. It is worth noting that in these regions of the world (except North America) over $90 \%$ of isolated $A$. baumannii strains in intensive care units were MDR. For North America, more than $60 \%$ of A. baumannii isolates were MDR, and this phenomenon remains unclear [38]. 


\subsection{Acinetobacter baumannii as an Uropathogenic Species}

Jiménez-Guerra et al. (2018) described the evolution of $A$. baumannii resistance in UTIs [39]. Among the isolated strains of A. baumannii, the highest percentage value of resistance was demonstrated for fosfomycin, aztreonam, ciprofloxacin, ceftazidime and cefepime. In vitro studies showed that colistin turned out to be the most effective antibiotic against these bacteria. Additionally, in the years 2013-2016 an increase in the resistance of A. baumannii isolates to imipenem, piperacillin-tazobactam and meropenem was noted. In addition to antibiotic resistance, $A$. baumannii may be resistant to bacteriophages. However, bacteriophage resistance may become a desirable trait. In vitro studies on two strains of A. baumannii (AB900 and A9844) showed that with the acquisition of resistance to specific bacteriophages ( $\Phi F G 02$ and $\Phi C O 01$, respectively) the bacteria lost their capsule on the bacterial surface. The loss of capsule was due to a defect in the overall production of capsule polysaccharides in bacteriophage-resistant bacteria. This defect contributed to a $2 \times$ decrease in the minimum inhibitory concentration (MIC) for ciprofloxacin and as much as a $16 \times$ decrease in the MIC for ceftazidime for the bacteriophage resistant AB900 strain compared to the wild strain. For bacteriophage resistant strain A9844, a $2 \times$ decrease in MIC was observed for minocycline, meropenem, cefepime and ampicillin with sulbactam compared to the wild strain. Additionally, resistance to bacteriophages of $A$. baumannii strains contributed to their sensitivity to the action of human complement [40].

Natural physiological mechanisms, such as the physicochemical properties of urine (e.g., the correct $\mathrm{pH}$ ), urination, or the structure of the urethra, prevent bacteria from entering the sterile parts of the urinary tract. Some virulent organisms, known as uropathogens, have the ability to overcome natural protective barriers. This may be favored by the presence of adhesive fimbriae, exemplified by the synergistically acting type $\mathrm{P}$ and type 1 fimbriae in uropathogenic E. coli, which significantly promotes colonization of renal tubules [41]. Another important virulence factor-proteases, have also been described in UTI-causing Acinetobacter strains [42,43]. Important enzymes encoded by bacteria and conducive to the development of infections, including UTIs, are haemolysins and aerobactins [44], which are involved in the acquisition of iron necessary for bacterial growth.

Another group of enzymes are phospholipases, which contribute to an increase in bacterial virulence by degrading the phospholipids of human cell membranes [45]. Although Acinetobacter is considered a non-motile bacterium, it has been shown to be capable of twitching motility, which may contribute to it spreading more easily [46]. A. baumannii is also characterized by an escape from the human immune system by removing zinc ions, thanks to which bacterial growth is not inhibited by one of the proteins of the immune system - calprotectin. High resistance to dryness and the ability to pump out antiseptics significantly contribute to the difficulties in fighting this pathogen [45].

Di Venanzio et al. (2019) conducted an analysis of Acinetobacter isolates identified in the BJC Healthcare System (BJC) in the period from January 2007 to August 2017 [43]. Among 2309 cases of Acinetobacter calcoaceticus-baumannii complex (Acbc), 22.2\% Acbc was isolated from urinary sources; other sources of Acbc isolation were respirators (33.9\%), soft tissue/musculoskeletal (31.9\%) and endovascular (10.4\%). The authors made an even broader analysis, reviewing clinical trials since 1995, which took into account the anatomical location of Acbc or A. baumannii isolates. An analysis of over 19,000 cases showed that the majority of isolates came from the respiratory tract (39.5\%) and soft tissue/musculoskeletal $(22.7 \%)$. The percentage share of uropathogenic isolates ranged from $6.1 \%$ to $29.3 \%$, and the average was $17.1 \%$ of all isolates (3410 from 19,957). From the above analysis it can be concluded that $A$. baumannii strains constitute a significant percentage of pathogens infecting the urinary tract (Table 1). 
Table 1. Anatomical sites of isolation of A. baumannii clinical strains.

\begin{tabular}{|c|c|c|c|c|c|c|c|c|}
\hline \multirow{2}{*}{$\begin{array}{l}\text { Total Isolate } \\
\text { Number }\end{array}$} & \multicolumn{5}{|c|}{ Anatomical Site of $A$. baumannii Isolation (\%) } & \multirow{2}{*}{$\begin{array}{l}\text { Region of } \\
\text { the World }\end{array}$} & \multirow[b]{2}{*}{ Collection Date } & \multirow[b]{2}{*}{ Reference } \\
\hline & $\begin{array}{l}\text { Urinary } \\
\text { Tract }\end{array}$ & $\begin{array}{c}\text { Respiratory } \\
\text { Tract }\end{array}$ & $\begin{array}{c}\text { Soft Tissue/ } \\
\text { Musculoskeletal }\end{array}$ & Endovascular & Other & & & \\
\hline 7046 & 20.4 & 38.7 & 26.3 & 6.2 & 8.5 & Hong Kong & 01.1990-11.1994 & [47] \\
\hline 1532 & 28.7 & 28.3 & 21.2 & 12.7 & 9.1 & Spain & 1991-1996 & [48] \\
\hline 4484 & 9.9 & 48.9 & 13.9 & 18.3 & 9.0 & USA & $1.1994-12.2011$ & [49] \\
\hline 826 & 9.0 & 36.2 & 4.2 & 46.0 & 4.6 & Latin America & $1.1997-12.2001$ & [50] \\
\hline 1444 & 18.0 & 35.0 & 18.0 & 25.0 & 4.0 & USA & $1.1998-12.2005$ & [51] \\
\hline 58 & 29.3 & 0.0 & 63.8 & 6.9 & 0.0 & Nigeria & 2001 & [52] \\
\hline 66 & 6.1 & 33.3 & 7.6 & 53.0 & 0.0 & Canada & 2007-2009 & [53] \\
\hline 2273 & 22.2 & 33.9 & 31.9 & 10.4 & 1.5 & USA & $1.2007-7.2017$ & [43] \\
\hline 167 & 10.2 & 32.3 & 44.3 & 6.0 & 7.2 & Malaysia & $10.2010-4.2011$ & [54] \\
\hline 1176 & 10.8 & 26.8 & 42.3 & 9.4 & 10.8 & Saudi Arabia & $1.2010-12.2013$ & [55] \\
\hline 140 & 13.6 & 0.0 & 37.1 & 22.9 & 26.4 & India & $8.2010-7.2011$ & [56] \\
\hline 645 & 8.8 & 77.2 & 5.3 & 2.0 & 1.0 & Japan & $10.2012-3.2013$ & [57] \\
\hline 100 & 13.0 & 59.0 & 15.0 & 12.0 & 1.0 & Iran & $5.2015-7.2016$ & [58] \\
\hline 19,957 & 17.1 & 39.5 & 22.7 & 13.2 & 7.5 & & Total & \\
\hline
\end{tabular}

The analysis shows that on average, $17.1 \%$ of $A$. baumannii strains are isolated from urinary sources, but only $2 \%$ of UTIs are caused by these bacteria. However, A. baumannii is the main pathogen causing UTIs associated with the use of catheters in intensive care units $[59,60]$. More than half of $A$. baumannii strains isolated from urine come from catheterized patients. Moreover, other infections caused by A. baumannii are often associated with the use of medical equipment, such as central venous lines or endotracheal [61]. Di Venanzio et al. (2019), to investigate the uropathogenesis of A. baumannii, used the catheter-associated UTI mouse model [43]. This model is frequently used to study the uropathogenic methicillin-resistant Staphylococcus aureus (MRSA), Group B Streptococcus, Escherichia coli and Enterococcus faecalis [62-64]. Two strains of A. baumannii isolated from urine were used to test the ability to colonize the kidneys and bladder of mice: UPAB1 and ATCC19606. The isolated MDR UPAB1 strain came from a patient with uncomplicated UTI; the ATCC19606 strain is widely used to study the virulence of $A$. baumannii in murine models of sepsis and pneumonia $[43,65]$. The bacteria were administered through an implant (transurethrally by a small piece of silicone tube) placed in the animal's urethra [43]. The results of the experiment show that infection with the UPAB1 strain caused a 5 log increase in bacterial count on the implants and in the bladders of mice $24 \mathrm{~h}$ after infection. A fluorescence microscope confirmed the presence of bacteria on the silicone implants and luminal urothelial surface, whereas the ATCC19606 strain was almost completely removed from the body of the mice $24 \mathrm{~h}$ after infection. This study showed that UPAB1 infects the urinary tract like other uropathogenic bacteria.

Sequencing of the UPAB1 genome indicated that this strain possesses the pAB5 plasmid, the presence of which affected uropathogenesis and was associated with a higher bacterial titer on the implant and urinary bladder of mice in the catheter-associated UTI (compared to the control without the plasmid). Completely different results were obtained for lung infection in mice caused by the UPAB1 strain. In the case of the wild-type strain (with the pAB5 plasmid), $36 \mathrm{~h}$ after intranasal administration, the bacterial titer was 1 to 4 logs lower in livers, lungs, kidneys, spleens and hearts compared to the infection with the strain without the plasmid. In addition, no deaths were reported among mice infected with the wild-type bacterial strain where infection with the strain without plasmid resulted in $40 \%$ mortality in the animals. The results suggest that $A$. baumannii strains show different survival rates depending on the anatomical location of the host, and additional studies are needed to thoroughly investigate their pathobiology [43]. 
In the United States, approximately 100,000 cases of catheter-UTIs are reported each year [66]. This may be due to the formation of a bacterial biofilm on the surface of the catheter [67]. Even more than $75 \%$ of A. baumannii strains are capable of producing biofilm, therefore the bacteria may contribute significantly to UTIs [68-70]. Braun and Vidotto (2004) isolated 13 strains of A. baumannii derived from urinary sources from patients aged 18 to 88 years. Six strains have been isolated from hospital patients and seven from outpatients. The susceptibility of these strains to selected antibiotics was tested, three strains from non-hospitalized patients were sensitive to the action of most of the antibiotics used. Interestingly, the remaining strains turned out to be resistant to amikacin, ceftriaxone, ciprofloxacin and trimethoprim-sulfamethoxazole. [71]. Pour et al. (2011) also described uropathogenic strains of $A$. baumannii. Researchers isolated 47 strains of $A$. baumannii and three strains of $A$. lwoffii from urinary tract and urinary catheter samples. The ability of the tested strains to produce biofilm was also assessed, and it turned out that biofilm forms better on polypropylene than on glass surfaces. Additionally, shaking promoted the formation of a bacterial biofilm. What is more, resistance to 27 different antibiotics was tested for six biofilm-forming strains of $A$. baumannii. These isolates were resistant to $97 \%$ of aminoglycosides, $94.4 \%$ of the cephalosporin group, $83.3 \%$ of $\beta$-lactams, $75 \%$ of quinolones, $66.6 \%$ of tetracycline and oxytetracycline, $33.3 \%$ of imipenem and $50 \%$ of the other antibiotics tested. Interestingly, all isolates were sensitive to colistin [72].

A. baumannii infections do not only affect humans, they also cause infections in animals. Kuzi et al. (2016) described UTIs in hospitalized dogs and cats caused by Acinetobacter calcoaceticus-baumannii complex (Acbc) [73]. A total of 19 dogs and four cats were hospitalized due to the primary disease. Twenty-two animals were treated in the intensive care unit and five of them were transferred to the general hospitalization ward after 1-3 days. The animals were hospitalized for 2 to 15 days. There were clinical signs among the animals (including: weakness 52\%, fever 39\%, urine turbidity 30\%) indicative of a healthcareassociated secondary Acbc infection (pneumonia, UTI, sepsis, cellulitis and septic arthritis). In total, 10 hospitalized animals (two cats and eight dogs) were diagnosed with UTI and the Acbc was isolated from the urine in two cats and seven dogs. All animals diagnosed with secondary Acbc urinary tract infection were previously catheterized. Antibiotics were given to all animals diagnosed with Acbc infection. As a result of infection, all dogs with the infection survived and two cats died [73].

Bacterial strains isolated from animals are also characterized by a significant increase in MDR [74]. The Acbc strains were isolated from cats and dogs from urine, blood, bronchoalveolar lavage fluid, kidneys, lungs, heart, and liver, as well as fluid aspirated from subcutaneous tissues with cellulitis. For all isolated Acbc strains, the antibiotic resistance profile was investigated. All of them were resistant to most of the tested antibiotics commonly used in hospitals: amoxicillin-clavulanic acid, amikacin, ampicillin, fluoroquinolones, gentamycin, sulfamethoxazole/trimethoprim, polymyxin B, florfenicol, third generation cephalosporins, second generation cephalosporins, first generation cephalosporins, imipenem and ticarcillin. The isolated strains turned out to be sensitive only to polymyxin-B (96\%), imipenem (74\%), ticarcillin (59\%) and amikacin (35\%). The above study shows that veterinary MDR Acbc infections are characterized by high mortality up to $70 \%$ [73].

It is important to remember that there is a significant problem regarding the possibility of transmitting zoonotic pathogens to humans, including bacteria from the ESKAPE group, such as A. baumannii [75]. The role of animals, especially dogs, in helping in the treatment of hospitalized patients is clearly emphasized, and despite their many benefits, they can pose a serious threat as carriers of pathogens.

\subsection{Bacteriophages as a Tool in the Fight against Uropathogenic Bacteria}

Bacteriophages were discovered over 100 years ago, first by microbiologist Frederick Twort in 1915 [76]. Then, in 1917, Felix d'Herelle published a paper about bacteriophages, as invisible microbes that were present in the filtrate of feces of people suffering from 
dysentery. He showed that the titer of bacteriophages increases with the development of the disease and reaches its highest value during recovery. d'Herelle tested bacteriophage therapy on himself and his relatives, and then on patients with dysentery and cholera. It was then used to heal wounds, and the bacteriophages were tested for avian typhosis caused by Salmonella gallinarum. Bacteriophages have been used against Pasteurella multocida in the treatment of bovine hemorrhagic septicaemia. However, the first paper on bacteriophage therapy appeared in 1921, published by Bruynoghe and Maisin [76]. Due to the discovery of antibiotics, the use of bacteriophages has been limited to Poland and Georgia [77]. Nowadays however, because of problems with antibiotic inefficiency, this method of treating bacterial infections has gained renewed interest.

Bacteriophage therapy, unlike antibiotics, does not damage the natural microbiota of both the human and animal body. Because bacteriophages are able to be amplified only with the presence of susceptible bacteria causing lysis of their cells, they are named self-limiting "drugs". What is more, bacteriophages may also be active against antibiotic-resistant strains of bacteria. Therefore, in people with bacterial infections, where antibiotics failed, it is possible to use lytic bacteriophages $[10,28]$ that also proved to be safe and well-tolerated by immunocompromised patients as well as people allergic to antibiotics. This is likely due to their structure, which is composed of proteins and nucleic acids only and therefore are considered as non-toxic [78]. In contrast to antibiotics, bacterial viruses that are most abundant in the environment can thus be sought and isolated from places where bacteria are present [79-81]. Bacteriophages can be found in almost any environment, and thus the costs associated with the production of bacteriophage preparations are lower than in the case of antibiotics [82]. Interestingly, a particularly desirable feature of bacteriophages is their ability to combat bacterial biofilm, the structure of which is difficult to penetrate and destroy by antibiotics. In addition, the potential of bacteriophage therapy efficacy against pathogenic microorganisms has been confirmed by different studies on animal models [83-86]. Due to the features mentioned above, bacteriophage therapy has become a promising and effective alternative to standard therapy for the treatment of UTIs also caused by MDR bacteria.

In the case of UTI treatment, natural bacteriophage cocktails, bacteriophage lytic enzymes or proteins (natural or engineered form), genetically engineered bacteriophages, as well as bacteriophages in combination with antibiotics may be used. Thus, bacteriophages can be detected in the urine, and despite its alkaline $\mathrm{pH}$, bacteriophages can remain active in the urine [22,87]. For example, UTIs by E. coli resulted in the appearance of bacteriophages specific for these bacteria in the urine $[88,89]$. Active bacteriophage particles specific to E. coli were detected in the urine after intravenous injection of purified preparation into the bloodstream [90]. Interestingly, specific bacteriophages in urine were also found in $30 \%$ of patients after oral administration of bacteriophage preparation [91].

Nowadays, bacteria are acquiring new and more sophisticated resistance mechanisms to the available antibiotics. Lytic bacteriophages are capable of destroying bacteria at the end of the infection cycle, and antibiotic resistance in the case of bacterial strains does not preclude effective bacteriophage therapy [78]. Therefore, bacteriophage therapy serves as a great tool to fight MDR bacterial infections [92], especially UTI caused by MDR $A$. baumannii.

UTIs are a serious social and economic problem. In the United States, as many as seven million medical visits and more than 100 thousand hospital admissions a year are caused by UTIs. A total of $15 \%$ of prescribed antibiotics are used to treat UTIs, at a cost of 1.6 billion dollars a year [93]. Pyelonephritis is a common case of patient UTIs and is associated with the patient's catheterization [94]. Another problem in the fight against UTI is the widespread use of antibiotics and the increasing phenomenon of resistance acquisition among uropathogenic strains $[95,96]$. Bacteriophage therapy is recognized as safe and effective in the treatment of UTI, as confirmed by clinical trials for the treatment of UTI and diarrhea in children caused by enteropathogenic E. coli, uropathogenic E. coli, enterotoxigenic E. coli, and P. aeruginosa [97-100]. Therefore, bacteriophages may be a real 
alternative for treating UTI. Due to the bacteriophage preparations, it is possible to combat specific bacterial hosts. Compared to bacterial resistance to antibiotics, bacteriophage resistance is slight, but present among some bacterial strains [101]. Nevertheless, there are many readily available sources of searching for new bacteriophages [102,103], and the process leading to the discovery of a new bacteriophage is relatively inexpensive and fast, therefore it is quite easy to match specific bacteriophages to specific bacterial strains. The use of a bacteriophage cocktail instead of monotherapy reduces the likelihood of the emergence of bacteriophage resistance. Each of the bacteriophages can be attached to a different receptor in a bacterial cell, and different bacteriophages can also act synergistically, so using a cocktail of several bacteriophages increases the probability of therapeutic effectiveness [104,105].

Using an intravenous catheter, Nishikawa et al. (2008) transurethrally injected an uropathogenic E. coli strain ECU5 $\left(5 \cdot 10^{9} \mathrm{CFU} / \mathrm{mL}\right)$ into the BALB/c mouse bladder [106]. Next, the purified T4 at multiplicities of infection (MOIs): $0.01-60$ or KEP10: MOI $=60$ bacteriophages were administered into the peritoneal cavity. For T4 bacteriophage at MOI $0.01,0.1,0.5,1$ and 60 survival rate after 3 days was $40 \%, 60 \%, 40 \%, 80 \%$ and $100 \%$ respectively. The administration of the KEP10 at MOI $=60$ rescued $90 \%$ of infected animals compared to the untreated control where $100 \%$ of the mice died [106].

Subsequently, UTI bacteriophage therapy was applied in a mouse model through the transurethral application of Cronobacter turicensis $\left(10^{11} \mathrm{CFU} / \mathrm{mL}\right)$. At the same time, specific bacteriophages were given intraperitoneal at a titer of $10^{11} \mathrm{PFU} / \mathrm{mL}$. After $24 \mathrm{~h}$, the bacterial count in the kidneys in mice treated with bacteriophage therapy reduced the bacterial count by $70 \%$ [107].

Sybesma et al. (2016) described the effect of commercial bacteriophage cocktails on uropathogenic clinical strains of K. pneumoniae and E. coli [108] in vitro. The results of a study of 41 clinical E. coli strains showed that the lytic activity of the Enko, Ses, Intesti, Pyo (before adaptation) and Pyo (after adaptation) bacteriophage cocktails was 92.7\%, $90.2 \%, 82.9 \%, 65.9 \%$ and $92.7 \%$, respectively. For nine clinical K. pneumoniae strains, the lytic activity of 10 bacteriophages from the Eliava collection ranged from $0 \%$ (vB_KlpR1, vB_KloxR2, vB_KlpR5 and vB_KlpR7 bacteriophage), 11\% (vB_KlpR6 bacteriophage), 22\% (vB_KlpR3, vB_KlpR4 and vB_KlpR8 bacteriophage), 56\% (v_BRKpM9 bacteriophage) up to even $100 \%$ (v_BRKpS10 bacteriophage).

Many of the uropathogenic bacterial strains have the ability to produce biofilm, especially in urinary catheters, which hinders the therapeutic effects of antibiotics $[67,109,110]$. The antimicrobial activity of bacteriophages against biofilm-producing A. baumannii strains was demonstrated in vitro in the study conducted by Vukotic et al. [111]. Two bacteriophages, isolated from Belgrade wastewater samples, were tested against 103 A. baumannii isolates, resulting in a higher host range for the ISTD bacteriophage compared to NOVI bacteriophage (36\% and $22 \%$, respectively). Moreover, a reduction in bacterial cell count in the biofilm formed on porous glass beads was observed $6 \mathrm{~h}$ after ISTD bacteriophage application. However, after $24 \mathrm{~h}$ of observation, the number of bacterial cells did not differ between the biofilm on which the bacteriophages were applied and the control biofilm.

The action of bacteriophages combined with antibiotics on the reduction in biofilm produced by uropathogenic strains of $A$. baumannii was tested in vitro [112]. Among 25 clinical uropathogenic strains of $A$. baumannii, one was selected AB20, which was characterized by a strong biofilm formation capacity, sensitivity to the bacteriophage used (Aba1-Aba-6) and resistance to antibiotics (ciprofloxacin, meropenem, levofloxacin, trimethoprim/sulfamethoxazole, netilmicin gentamicin, and imipenem). The bacterial biofilm produced after $24 \mathrm{~h}$, immersed in human urine, was treated with 1/2 MIC and 1/4 MIC of antibiotics: ciprofloxacin (MIC = 8), levofloxacin $(\mathrm{MIC}=16)$, trimethoprim/sulfamethoxazole $(\mathrm{MIC}=64)$, amikacin $(\mathrm{MIC}=32)$, tobramycin $(\mathrm{MIC}=2)$, gentamicin $(\mathrm{MIC}=64)$, colistin $(\mathrm{MIC}=1)$, imipenem $(\mathrm{MIC}=16)$, meropenem $(\mathrm{MIC}=32)$. Then, a bacteriophage cocktail (Aba-1, Aba-2, Aba-3, Aba-4, and Aba-6) with a titer of $1 \cdot 10^{7} \mathrm{PFU} / \mathrm{mL}$ was added to each sample with an antibiotic. After $6 \mathrm{~h}$ of incubation, the highest level of biofilm biomass re- 
duction was recorded for bacteriophages combined with trimethoprim/sulfamethoxazole $98.6 \%$ and $94.3 \%$ for $1 / 2$ and $1 / 4$ MIC, respectively. The use of ciprofloxacin in combination with the bacteriophage cocktail resulted in a reduction of $93.3 \%$ and $87 \%$ for $1 / 2$ and $1 / 4$ MIC, respectively. For the remaining antibiotics, the results were similar, only amikacin and levofloxacin did not act synergistically with bacteriophages. Additionally, the weakest result was recorded for the combination of the bacteriophage cocktail with colistin, where increased biofilm formation was noted. The bacteriophage cocktail alone reduced the biofilm biomass in $77 \%$. These studies indicate that bacteriophage therapy in the future may be a useful tool in the fight against UTIs in humans. So far, no studies have been conducted on the use of bacteriophage therapy in the treatment of UTIs caused by A. baumannii in an animal model. However, other work on treating UTIs caused by uropathogenic strains (E. coli, P. aeruginosa, Cronobacter spp.) has shown positive results [97-100,107]. Due to the differences between the human body and the organisms of various animals, the results obtained in vivo studies with the use of animal models cannot be fully related to the human body, but they significantly help, e.g., in choosing the most advantageous route of bacteriophage administration or assessing the appropriate therapeutic dose [113].

The possibility of using bacteriophage-derived enzymes as effective tools to combat UTI is also emphasized [114]. Despite the satisfactory results of the action of bacteriophage lysins mainly on Gram-positive bacteria, promising studies of these enzymes in $A$. baumannii sepsis in a mouse model have been conducted [115].

Bacteriophages are capable of fighting bacterial biofilm that can form on the catheters. Additionally, bacteriophages can be used in conjunction with antibiotics. Grygorcewicz et al. (2020) in their work presented promising results of the fight against A. baumannii biofilm with the use of bacteriophage cocktail combined with antibiotics in a human urine model. The use of a bacteriophage cocktail (Aba-1, Aba-2, Aba-3, Aba-4, and Aba-6) in combination with ciprofloxacin, trimethoprim/sulfamethoxazole, gentamicin, tobramycin, imipenem and meropenem resulted in a significant reduction in the biofilm biomass of $A$. baumannii AB20. The best combination turned out to be the combination of the bacteriophage cocktail with trimethoprim/sulfamethoxazole, where the reduction in biofilm reached $94.3 \%$ and $98.6 \%$, with $1 / 4$ and $1 / 2 \mathrm{MIC}$, respectively [112].

Studies have also been carried out using the Pyo bacteriophage in the treatment of patients with UTI [97]. Of 118 clinical uropathogens (P. aeruginosa, E. coli, Streptococcus spp., Proteus mirabilis, S. aureus), $41 \%$ of the strains were sensitive to the action of the Pyo bacteriophage, and after its four-fold adaptation, the sensitivity of the bacteria increased to $75 \%$. In the second part of the study, urine samples were collected from nine patients after transurethral resection of the prostate. E. coli was detected in the samples of four patients, Streptococcus spp. in two, Enterococcus spp. in two and P. aeruginosa in one of the nine patients. The patients were administered the Pyo bacteriophage intravesically. The bacteriophage was administered twice a day for 7 days (starting from the first day after the treatment) at a volume of $20 \mathrm{~mL}$. The bacteriophage-containing solution was in the bladder for $0.5-1 \mathrm{~h}$. After treatment with bacteriophages, six of nine patients had a 1 to $5 \log$ reduction in urine bacterial counts. Additionally, no side effects of bacteriophage therapy were noted. Other studies show that bacteriophage therapy in treating UTI has not been shown to be more effective than washing the bladder with a placebo solution and standard antibiotic therapy [116].

In addition to the positive aspects, bacteriophage therapy also has limitations. One of them is the possibility of pathogens acquiring bacteriophage resistance. Therefore, bacteriophage cocktails are used due to the lower probability of resistance to all bacteriophages present in the cocktail [101]. In addition, UTI can be caused by more than one bacterial strain, therefore monotherapy in comparison to bacteriophage cocktails may turn out to be unsuccessful [117]. Another limitation of bacteriophage therapy may be the limited access of bacteriophages to biofilm-building bacteria-due to the layers of extracellular polymeric substances (EPS) surrounding the bacteria [118]. A negative effect of bacteriophage therapy may be the adverse response of the immune system due to the sudden lysis of bacteria 
and the release of toxic lipopolysaccharides [119]. A serious limitation of bacteriophage therapy is that there is not much evidence that the use of bacteriophages alone (without antibiotics) is capable of combating UTIs [120].

Although bacteriophage therapy is not an approved method of treating UTI, further research will optimize this method and determine the role of bacteriophages in the fight against UTI [116]. The results suggest that bacteriophage therapy has great potential in treating UTIs, which needs confirmation in the case of UTI caused by A. baumannii strains.

\section{Conclusions}

The species Acinetobacter baumannii has been classified to the list of the ten most serious threats to public health and as a critical priority group. Currently, many bacteria, including A. baumannii [121], exhibit resistance to a wide spectrum of available antibiotics [122]. Consequently, antibiotics cannot be considered as a real and effective agent against bacterial infections caused by these pathogens. Moreover, in addition to being resistant to many antimicrobial agents, the Acinetobacter species has many characteristics that facilitate its spread and increase pathogenicity, such as the aforementioned ability to produce enzymes that allow more efficient acquisition of ingredients necessary for the survival of bacteria or the ability to escape from the human immune system.

An infection of the urinary tract is common and causes many difficulties during treatment due to the antibiotic resistance among bacterial strains and the side effects observed after and/or during antibiotic therapy, therefore other treatments for UTI should be considered [123-127]. Previous studies have shown that UTIs pose serious medical, social and economic problems [6-8]. One of the possibilities may be bacteriophage therapy, which can prove to be an effective method to solve this problem. Future studies on the treatment of UTIs caused by uropathogenic strains of A. baumannii may have a bearing on the use of this solution in humans in the future. Further research should focus on developing an animal model of UTI caused by A. baumannii. Appropriately selected bacteriophages may constitute the composition of a bacteriophage cocktail capable of fighting infections caused by $A$. baumannii [128]. Future studies in animal models may lead to the development of a treatment model for A. baumannii UTI in humans.

Author Contributions: N.B. drafted the main part of the manuscript, M.C. and E.J.-M. contributed to the parts of the manuscript, A.G. and E.J.-M. provided support and conceptual advice at all stages of manuscript preparation; all authors revised the manuscript. All authors have read and agreed to the published version of the manuscript.

Funding: This work was supported by statutory funds from Ludwik Hirszfeld Institute of Immunology and Experimental Therapy, Polish Academy of Science.

Conflicts of Interest: A. Górski is a co-inventor of patents owned by L. Hirszfeld Institute and covered bacteriophage preparations. Other authors declared that the research was conducted without any commercial or financial relationships that could be construed as a potential conflict of interest.

\section{References}

1. Öztürk, R.; Murt, A. Epidemiology of urological infections: A global burden. World J. Urol. 2020, 38, 2669-2679. [CrossRef]

2. Flores-Mireles, A.L.; Walker, J.N.; Caparon, M.; Hultgren, S.J. Urinary tract infections: Epidemiology, mechanisms of infection and treatment options. Nat. Rev. Microbiol. 2015, 13, 269-284. [CrossRef] [PubMed]

3. Fournier, P.E.; Richet, H. The epidemiology and control of Acinetobacter baumannii in health care facilities. Clin. Infect. Dis. 2006, 42, 692-699. [CrossRef] [PubMed]

4. Odegaard, J.I.; Hsieh, M.H. Immune responses to Schistosoma haematobium infection. Parasite Immunol. 2014, 36, 428-438. [CrossRef] [PubMed]

5. Sobel, J.D.; Fisher, J.F.; Kauffman, C.A.; Newman, C.A. Candida urinary tract infections—Epidemiology. Clin. Infect. Dis. 2011, 52, S433-S436. [CrossRef]

6. Foxman, B.; Barlow, R.; D'Arcy, H.; Gillespie, B.; Sobel, J.D. Urinary tract infection: Self-reported incidence and associated costs. Ann. Epidemiol. 2000, 10, 509-515. [CrossRef]

7. Foxman, B. Urinary tract infection syndromes: Occurrence, recurrence, bacteriology, risk factors, and disease burden. Infect. Dis. Clin. N. Am. 2014, 28, 1-13. [CrossRef] 
8. Wang, C.H.; Fang, C.C.; Chen, N.C.; Liu, S.S.; Yu, P.H.; Wu, T.Y.; Chen, W.T.; Lee, C.C.; Chen, S.C. Cranberry-containing products for prevention of urinary tract infections in susceptible populations: A systematic review and meta-analysis of randomized controlled trials. Arch. Intern. Med. 2012, 172, 988-996. [CrossRef]

9. Foxman, B. The epidemiology of urinary tract infection. Nat. Rev. Urol. 2010, 7, 653-660. [CrossRef]

10. Górski, A.; Międzybrodzki, R.; Łobocka, M.; Głowacka-Rutkowska, A.; Bednarek, A.; Borysowski, J.; Jończyk-Matysiak, E.; Łusiak-Szelachowska, M.; Weber-Dąbrowska, B.; Bagińska, N.; et al. Bacteriophage Therapy: What Have We Learned? Viruses 2018, 10, 288. [CrossRef]

11. Xie, R.; Zhang, X.D.; Zhao, Q.; Peng, B.; Zheng, J. Analysis of global prevalence of antibiotic resistance in Acinetobacter baumannii infections disclosed a faster increase in OECD countries. Emerg. Microbes Infect. 2018, 7, 31. [CrossRef]

12. Raad, I.I.; Mohamed, J.A.; Reitzel, R.A.; Jiang, Y.; Dvorak, T.L.; Ghannoum, M.A.; Hachem, R.Y.; Chaftari, A.M. The prevention of biofilm colonization by multidrug-resistant pathogens that cause ventilator-associated pneumonia with antimicrobial-coated endotracheal tubes. Biomaterials 2011, 32, 2689-2694. [CrossRef]

13. Joly-Guillou, M.L. Clinical impact and pathogenicity of Acinetobacter. Clin. Microbiol. Infect. 2005, 11, 868-873. [CrossRef]

14. Sievert, D.M.; Ricks, P.; Edwards, J.R.; Schneider, A.; Patel, J.; Srinivasan, A.; Kallen, A.; Limbago, B.; Fridkin, S. National Healthcare Safety Network (NHSN) Team and Participating NHSN Facilities. Antimicrobial-resistant pathogens associated with healthcare-associated infections: Summary of data reported to the National Healthcare Safety Network at the Centers for Disease Control and Prevention, 2009-2010. Infect. Control. Hosp. Epidemiol. 2013, 34, 1-14.

15. Davis, K.A.; Moran, K.A.; McAllister, C.K.; Gray, P.J. Multidrug-resistant Acinetobacter extremity infections in soldiers. Emerg. Infect. Dis. 2005, 11, 1218-1224. [CrossRef] [PubMed]

16. Yun, H.C.; Branstetter, J.G.; Murray, C.K. Osteomyelitis in military personnel wounded in Iraq and Afghanistan. J. Trauma 2008, 64, S163-S168. [CrossRef]

17. Carvalho, V.C.; Oliveira, P.R.; Dal-Paz, K.; Paula, A.P.; Félix Cda, S.; Lima, A.L. Gram-negative osteomyelitis: Clinical and microbiological profile. Braz. J. Infect. Dis. 2012, 16, 63-67. [CrossRef]

18. Saballs, M.; Pujol, M.; Tubau, F.; Peña, C.; Montero, A.; Domínguez, M.A.; Gudiol, F.; Ariza, J. Rifampicin/imipenem combination in the treatment of carbapenem-resistant Acinetobacter baumannii infections. J. Antimicrob. Chemother. 2006, 58, 697-700. [CrossRef] [PubMed]

19. Fraenkel, C.J.; Ullberg, M.; Bernander, S.; Ericson, E.; Larsson, P.; Rydberg, J.; Törnqvist, E.; Melhus, A. In vitro activities of three carbapenems against recent bacterial isolates from severely ill patients at Swedish hospitals. Scand. J. Infect. Dis. 2006, 38, 853-859. [CrossRef] [PubMed]

20. Scott, P.; Deye, G.; Srinivasan, A.; Murray, C.; Moran, K.; Hulten, E.; Fishbain, J.; Craft, D.; Riddell, S.; Lindler, L.; et al. An outbreak of multidrug-resistant Acinetobacter baumannii-calcoaceticus complex infection in the US military health care system associated with military operations in Iraq. Clin. Infect. Dis. 2007, 44, 1577-1584. [CrossRef]

21. LaVergne, S.; Hamilton, T.; Biswas, B.; Kumaraswamy, M.; Schooley, R.T.; Wooten, D. Bacteriophage Therapy for a MultidrugResistant Acinetobacter baumannii Craniectomy Site Infection. Open Forum Infect. Dis. 2018, 5, ofy064. [CrossRef]

22. Jończyk, E.; Kłak, M.; Międzybrodzki, R.; Górski, A. The influence of external factors on bacteriobacteriophages-Review. Folia Microbiol. 2011, 56, 191-200. [CrossRef]

23. Lucena, F.; Ribas, F.; Duran, A.E.; Skraber, S.; Gantzer, C.; Campos, C.; Morón, A.; Calderón, E.; Jofre, J. Occurrence of bacterial indicators and bacteriobacteriophages infecting enteric bacteria in groundwater in different geographical areas. J. Appl. Microbiol. 2006, 101, 96-102. [CrossRef]

24. Gantzer, C.; Henny, J.; Schwartzbrod, L. Bacteroides fragilis and Escherichia coli bacteriobacteriophages in human faeces. Int. J. Hyg. Environ. Health 2002, 205, 325-328. [CrossRef]

25. Yang, H.; Liang, L.; Lin, S.; Jia, S. Isolation and characterization of a virulent bacteriobacteriophage AB1 of Acinetobacter baumannii. BMC Microbiol. 2010, 10, 131. [CrossRef]

26. Lin, N.T.; Chiou, P.Y.; Chang, K.C.; Chen, L.K.; Lai, M.J. Isolation and characterization of phi AB2: A novel bacteriobacteriophage of Acinetobacter baumannii. Res. Microbiol. 2010, 161, 308-314. [CrossRef] [PubMed]

27. Ghajavand, H.; Esfahani, B.N.; Havaei, A.; Fazeli, H.; Jafari, R.; Moghim, S. Isolation of bacteriobacteriophages against multidrug resistant Acinetobacter baumannii. Res. Pharm. Sci. 2017, 12, 373-380.

28. Górski, A.; Wazna, E.; Dabrowska, B.W.; Dabrowska, K.; Switała-Jeleń, K.; Miedzybrodzki, R. Bacteriobacteriophage translocation. FEMS Immunol. Med. Microbiol. 2006, 46, 313-319. [CrossRef]

29. Żaczek, M.; Weber-Dabrowska, B.; Międzybrodzki, R.; Górski, A. Bacteriophage Prevalence in the Human Urinary Tract-Current Knowledge and Therapeutic Implications. Microorganisms 2020, 8, 1802. [CrossRef] [PubMed]

30. Blanco-Picazo, P.; Fernández-Orth, D.; Brown-Jaque, M.; Miró, E.; Espinal, P.; Rodríguez-Rubio, L.; Muniesa, M.; Navarro, F. Unravelling the consequences of the bacteriobacteriophages in human samples. Sci. Rep. 2020, 10, 6737. [CrossRef] [PubMed]

31. García-Quintanilla, M.; Pulido, M.R.; López-Rojas, R.; Pachón, J.; McConnell, M.J. Emerging therapies for multidrug resistant Acinetobacter baumannii. Trends Microbiol. 2013, 21, 157-163. [CrossRef]

32. Jeon, J.; Ryu, C.M.; Lee, J.Y.; Park, J.H.; Yong, D.; Lee, K. In Vivo Application of Bacteriobacteriophage as a Potential Therapeutic Agent To Control OXA-66-Like Carbapenemase-Producing Acinetobacter baumannii Strains Belonging to Sequence Type 357. Appl. Environ. Microbiol. 2016, 82, 4200-4208. [CrossRef] 
33. Wang, Y.; Mi, Z.; Niu, W.; An, X.; Yuan, X.; Liu, H.; Li, P.; Liu, Y.; Feng, Y.; Huang, Y.; et al. Intranasal treatment with bacteriobacteriophage rescues mice from Acinetobacter baumannii-mediated pneumonia. Future Microbiol. 2016, 11, 631-641. [CrossRef] [PubMed]

34. Shivaswamy, V.C.; Kalasuramath, S.B.; Sadanand, C.K.; Basavaraju, A.K.; Ginnavaram, V.; Bille, S.; Ukken, S.S.; Pushparaj, U.N. Ability of bacteriobacteriophage in resolving wound infection caused by multidrug-resistant Acinetobacter baumannii in uncontrolled diabetic rats. Microb. Drug Resist. 2015, 21, 171-177. [CrossRef]

35. Livermore, D.M. Current epidemiology and growing resistance of gram-negative pathogens. Korean J. Intern. Med. 2012, 27, 128-142. [CrossRef] [PubMed]

36. Falagas, M.E.; Karveli, E.A.; Siempos, I.I.; Vardakas, K.Z. Acinetobacter infections: A growing threat for critically ill patients. Epidemiol. Infect. 2008, 136, 1009-1019. [CrossRef]

37. Ahmed, N.H.; Hussain, T.; Biswal, I. Antimicrobial resistance of bacterial isolates from respiratory secretions of ventilated patients in a multi-specialty hospital. Avicenna J. Med. 2015, 5, 74-78. [CrossRef]

38. Lob, S.H.; Hoban, D.J.; Sahm, D.F.; Badal, R.E. Regional differences and trends in antimicrobial susceptibility of Acinetobacter baumannii. Int. J. Antimicrob. Agents 2016, 47, 317-323. [CrossRef] [PubMed]

39. Jiménez-Guerra, G.; Heras-Cañas, V.; Gutiérrez-Soto, M.; Del Pilar Aznarte-Padial, M.; Expósito-Ruiz, M.; Navarro-Marí, J.M.; Gutiérrez-Fernández, J. Urinary tract infection by Acinetobacter baumannii and Pseudomonas aeruginosa: Evolution of antimicrobial resistance and therapeutic alternatives. J. Med. Microbiol. 2018, 67, 790-797. [CrossRef] [PubMed]

40. Gordillo Altamirano, F.; Forsyth, J.H.; Patwa, R.; Kostoulias, X.; Trim, M.; Subedi, D.; Archer, S.K.; Morris, F.C.; Oliveira, C.; Kielty, L.; et al. Bacteriobacteriophage-resistant Acinetobacter baumannii are resensitized to antimicrobials. Nat. Microbiol. 2021, 6, 157-161. [CrossRef]

41. Melican, K.; Sandoval, R.M.; Kader, A.; Josefsson, L.; Tanner, G.A.; Molitoris, B.A.; Richter-Dahlfors, A. Uropathogenic Escherichia coli $\mathrm{P}$ and Type 1 fimbriae act in synergy in a living host to facilitate renal colonization leading to nephron obstruction. PLoS Pathog. 2011, 7, e1001298. [CrossRef]

42. Kinsella, R.L.; Lopez, J.; Palmer, L.D.; Salinas, N.D.; Skaar, E.P.; Tolia, N.H.; Feldman, M.F. Defining the interaction of the protease CpaA with its type II secretion chaperone CpaB and its contribution to virulence in Acinetobacter species. J. Biol. Chem. 2017, 292, 19628-19638. [CrossRef]

43. Di Venanzio, G.; Flores-Mireles, A.L.; Calix, J.J.; Haurat, M.F.; Scott, N.E.; Palmer, L.D.; Potter, R.F.; Hibbing, M.E.; Friedman, L.; Wang, B.; et al. Urinary tract colonization is enhanced by a plasmid that regulates uropathogenic Acinetobacter baumannii chromosomal genes. Nat. Commun. 2019, 10, 2763. [CrossRef]

44. Raeispour, M.; Ranjbar, R. Antibiotic resistance, virulence factors and genotyping of Uropathogenic Escherichia coli strains. Antimicrob. Resist. Infect. Control 2018, 7, 118. [CrossRef]

45. Ayoub Moubareck, C.; Hammoudi Halat, D. Insights into Acinetobacter baumannii: A Review of Microbiological, Virulence, and Resistance Traits in a Threatening Nosocomial Pathogen. Antibiotics 2020, 9, 119. [CrossRef] [PubMed]

46. Harding, C.M.; Tracy, E.N.; Carruthers, M.D.; Rather, P.N.; Actis, L.A.; Munson, R.S., Jr. Acinetobacter baumannii strain M2 produces type IV pili which play a role in natural transformation and twitching motility but not surface-associated motility. $m B i o$ 2013, 4, e00360. [CrossRef]

47. Siau, H.; Yuen, K.Y.; Wong, S.S.; Ho, P.L.; Luk, W.K. The epidemiology of acinetobacter infections in Hong Kong. J. Med. Microbiol. 1996, 44, 340-347. [CrossRef] [PubMed]

48. Ruiz, J.; Núñez, M.L.; Pérez, J.; Simarro, E.; Martínez-Campos, L.; Gómez, J. Evolution of resistance among clinical isolates of Acinetobacter over a 6-year period. Eur. J. Clin. Microbiol. Infect. Dis. 1999, 18, 292-295.

49. Munoz-Price, L.S.; Arheart, K.; Nordmann, P.; Boulanger, A.E.; Cleary, T.; Alvarez, R.; Pizano, L.; Namias, N.; Kett, D.H.; Poirel, L. Eighteen years of experience with Acinetobacter baumannii in a tertiary care hospital. Crit. Care Med. 2013, 41, $2733-2742$. [CrossRef] [PubMed]

50. Tognim, M.C.; Andrade, S.S.; Silbert, S.; Gales, A.C.; Jones, R.N.; Sader, H.S. Resistance trends of Acinetobacter spp. in Latin America and characterization of international dissemination of multi-drug resistant strains: Five-year report of the SENTRY Antimicrobial Surveillance Program. Int. J. Infect. Dis. 2004, 8, 284-291. [CrossRef] [PubMed]

51. Perencevich, E.N.; McGregor, J.C.; Shardell, M.; Furuno, J.P.; Harris, A.D.; Morris, J.G., Jr.; Fisman, D.N.; Johnson, J.A. Summer Peaks in the Incidences of Gram-Negative Bacterial Infection Among Hospitalized Patients. Infect. Control Hosp. Epidemiol. 2008, 29, 1124-1131. [CrossRef]

52. Iregbu, K.C.; Ogunsola, F.T.; Odugbemi, T.O. Infections caused by Acinetobacter species and their susceptibility to 14 antibiotics in Lagos University Teaching Hospital, Lagos. West. Afr. J. Med. 2002, 21, 226-229. [CrossRef]

53. McCracken, M.; Mataseje, L.F.; Loo, V.; Walkty, A.; Adam, H.J.; Hoban, D.J.; Zhanel, G.G.; Mulvey, M.R. Canadian Antimicrobial Resistance Alliance (CARA). Characterization of Acinetobacter baumannii and meropenem-resistant Pseudomonas aeruginosa in Canada: Results of the CANWARD 2007-2009 study. Diagn. Microbiol. Infect. Dis. 2011, 69, 335-341. [CrossRef]

54. Biglari, S.; Hanafiah, A.; Mohd Puzi, S.; Ramli, R.; Rahman, M.; Lopes, B.S. Antimicrobial Resistance Mechanisms and Genetic Diversity of Multidrug-Resistant Acinetobacter baumannii Isolated from a Teaching Hospital in Malaysia. Microb. Drug Resist. 2017, 23, 545-555. [CrossRef] [PubMed] 
55. Al Mobarak, M.F.; Matbuli, R.M.; Meir, H.; Al Gehani, N.; ElToukhy, A.A.M.; Al Qureshey, K.F.; Mutwalli, A.H.; Abdulaziz, A.M.; Hadhoud, A. Antimicrobial resistance patterns among Acinetobacter baumannii isolated from King Abdulaziz Hospital, Jeddah, Saudi Arabia, Four-Year Surveillance Study (2010-2013). Egypt J. Med. Microbiol. 2014, 23, 53-60. [CrossRef]

56. Sinha, N.; Agarwal, J.; Srivastava, S.; Singh, M. Analysis of carbapenem-resistant Acinetobacter from a tertiary care setting in North India. Indian J. Med. Microbiol. 2013, 31, 60-63. [PubMed]

57. Matsui, M.; Suzuki, M.; Suzuki, M.; Yatsuyanagi, J.; Watahiki, M.; Hiraki, Y.; Kawano, F.; Tsutsui, A.; Shibayama, K.; Suzuki, S. Distribution and Molecular Characterization of Acinetobacter baumannii International Clone II Lineage in Japan. Antimicrob. Agents Chemother. 2018, 62, e02190. [CrossRef] [PubMed]

58. Fallah, A.; Rezaee, M.A.; Hasani, A.; Barhaghi, M.H.S.; Kafil, H.S. Frequency of bap and cpaA virulence genes in drug resistant clinical isolates of Acinetobacter baumannii and their role in biofilm formation. Iran. J. Basic Med. Sci. 2017, 20, 849-855. [PubMed]

59. Kumar, S.; Sen, P.; Gaind, R.; Verma, P.K.; Gupta, P.; Suri, P.R.; Nagpal, S.; Rai, A.K. Prospective surveillance of device-associated health care-associated infection in an intensive care unit of a tertiary care hospital in New Delhi, India. Am. J. Infect. Control 2018, 46, 202-206. [CrossRef] [PubMed]

60. Ding, R.; Li, X.; Zhang, X.; Zhang, Z.; Ma, X. The Epidemiology of Symptomatic Catheter-associated Urinary Tract Infections in the Intensive Care Unit: A 4-year Single Center Retrospective Study. Urol. J. 2019, 16, 312-317.

61. Cisneros, J.M.; Reyes, M.J.; Pachón, J.; Becerril, B.; Caballero, F.J.; García-Garmendía, J.L.; Ortiz, C.; Cobacho, A.R. Bacteremia due to Acinetobacter baumannii: Epidemiology, clinical findings, and prognostic features. Clin. Infect. Dis. 1996, 22, 1026-1032. [CrossRef] [PubMed]

62. Walker, J.N.; Flores-Mireles, A.L.; Pinkner, C.L.; Schreiber, H.L., IV; Joens, M.S.; Park, A.M.; Potretzke, A.M.; Bauman, T.M.; Pinkner, J.S.; Fitzpatrick, J.A.J.; et al. Catheterization alters bladder ecology to potentiate Staphylococcus aureus infection of the urinary tract. Proc. Natl. Acad. Sci. USA 2017, 114, E8721-E8730. [CrossRef] [PubMed]

63. Xu, W.; Flores-Mireles, A.L.; Cusumano, Z.T.; Takagi, E.; Hultgren, S.J.; Caparon, M.G. Host and bacterial proteases influence biofilm formation and virulence in a murine model of enterococcal catheter-associated urinary tract infection. NPJ Biofilms Microbiom. 2017, 3, 28. [CrossRef]

64. Hopkins, W.J.; Gendron-Fitzpatrick, A.; Balish, E.; Uehling, D.T. Time course and host responses to Escherichia coli urinary tract infection in genetically distinct mouse strains. Infect. Immun. 1998, 66, 2798-2802. [CrossRef] [PubMed]

65. Gaddy, J.A.; Arivett, B.A.; McConnell, M.J.; López-Rojas, R.; Pachón, J.; Actis, L.A. Role of acinetobactin-mediated iron acquisition functions in the interaction of Acinetobacter baumannii strain ATCC 19606T with human lung epithelial cells, Galleria mellonella caterpillars, and mice. Infect. Immun. 2012, 80, 1015-1024. [CrossRef]

66. Zarb, P.; Coignard, B.; Griskeviciene, J.; Muller, A.; Vankerckhoven, V.; Weist, K.; Goossens, M.M.; Vaerenberg, S.; Hopkins, S.; Catry, B.; et al. The European Centre for Disease Prevention and Control (ECDC) pilot point prevalence survey of healthcareassociated infections and antimicrobial use. Euro. Surveill. 2012, 17, 20316. [CrossRef]

67. Stickler, D.J. Bacterial biofilms in patients with indwelling urinary catheters. Nat. Clin. Pract. Urol. 2008, 5, 598-608. [CrossRef]

68. Abdi-Ali, A.; Hendiani, S.; Mohammadi, P.; Gharavi, S. Assessment of biofilm formation and resistance to imipenem and ciprofloxacin among clinical isolates of Acinetobacter baumannii in Tehran. Jundishapur J. Microbiol. 2014, 7, e8606. [CrossRef] [PubMed]

69. Azizi, O.; Shahcheraghi, F.; Salimizand, H.; Modarresi, F.; Shakibaie, M.R.; Mansouri, S.; Ramazanzadeh, R.; Badmasti, F.; Nikbin, V. Molecular analysis and expression of bap gene in biofilm-forming multi-drug-resistant Acinetobacter baumannii. Rep. Biochem. Mol. Biol. 2016, 5, 62-72.

70. Thummeepak, R.; Kongthai, P.; Leungtongkam, U.; Sitthisak, S. Distribution of virulence genes involved in biofilm formation in multi-drug resistant Acinetobacter baumannii clinical isolates. Int. Microbiol. 2016, 19, 121-129. [CrossRef] [PubMed]

71. Braun, G.; Vidotto, M.C. Evaluation of adherence, hemagglutination, and presence of genes codifying for virulence factors of Acinetobacter baumannii causing urinary tract infection. Mem. Inst Oswaldo Cruz 2004, 99, 839-844. [CrossRef]

72. Pour, N.K.; Dusane, D.H.; Dhakephalkar, P.K.; Zamin, F.R.; Zinjarde, S.S.; Chopade, B.A. Biofilm formation by Acinetobacter baumannii strains isolated from urinary tract infection and urinary catheters. FEMS Immunol. Med. Microbiol. 2011, 62, 328-338. [CrossRef]

73. Kuzi, S.; Blum, S.E.; Kahane, N.; Adler, A.; Hussein, O.; Segev, G.; Aroch, I. Multi-drug-resistant Acinetobacter calcoaceticusAcinetobacter baumannii complex infection outbreak in dogs and cats in a veterinary hospital. J. Small Anim. Pract. 2016, 57, 617-625. [CrossRef]

74. Zordan, S.; Prenger-Berninghoff, E.; Weiss, R.; van der Reijden, T.; van den Broek, P.; Baljer, G.; Dijkshoorn, L. Multidrug-resistant Acinetobacter baumannii in veterinary clinics, Germany. Emerg. Infect. Dis. 2011, 17, 1751-1754. [CrossRef] [PubMed]

75. Santaniello, A.; Sansone, M.; Fioretti, A.; Menna, L.F. Systematic Review and Meta-Analysis of the Occurrence of ESKAPE Bacteria Group in Dogs, and the Related Zoonotic Risk in Animal-Assisted Therapy, and in Animal-Assisted Activity in the Health Context. Int. J. Environ. Res. Public Health 2020, 17, 3278. [CrossRef]

76. Abedon, S.T.; Kuhl, S.J.; Blasdel, B.G.; Kutter, E.M. Bacteriobacteriophage. 2011 Mar; 1:66-85; Bacteriobacteriophage therapy. Summers WC. Annu. Rev. Microbiol. 2001, 55, 437-451.

77. Reardon, S. Bacteriophage therapy gets revitalized. Nature 2014, 510, 15-16. [CrossRef]

78. Loc-Carrillo, C.; Abedon, S.T. Pros and cons of bacteriophage therapy. Bacteriobacteriophage 2011, 1, 111-114. [CrossRef] [PubMed] 
79. Broudy, T.B.; Fischetti, V.A. In vivo lysogenic conversion of Tox(-) Streptococcus pyogenes to Tox(+) with Lysogenic Streptococci or free bacteriophage. Infect. Immun. 2003, 71, 3782-3786. [CrossRef] [PubMed]

80. Brüssow, H.; Kutter, E. Bacteriophage Ecology. In Bacteriobacteriophages Biology and Applications, 1st ed.; Kutter, E., Sulakvelidze, A., Eds.; CRC Press: Boca Raton, FL, USA, 2005; pp. 129-163.

81. Hanlon, G.W. Bacteriobacteriophages: An appraisal of their role in the treatment of bacterial infections. Int. J. Antimicrob. Agents 2007, 30, 118-128. [CrossRef] [PubMed]

82. Gordillo Altamirano, F.L.; Barr, J.J. Bacteriophage Therapy in the Postantibiotic Era. Clin. Microbiol. Rev. 2019, 32 , e00066. [CrossRef]

83. Capparelli, R.; Ventimiglia, I.; Roperto, S.; Fenizia, D.; Iannelli, D. Selection of an Escherichia coli O157:H7 bacteriobacteriophage for persistence in the circulatory system of mice infected experimentally. Clin. Microbiol. Infect. 2006, 12, 248-253. [CrossRef]

84. Watanabe, R.; Matsumoto, T.; Sano, G.; Ishii, Y.; Tateda, K.; Sumiyama, Y.; Uchiyama, J.; Sakurai, S.; Matsuzaki, S.; Imai, S.; et al. Efficacy of bacteriobacteriophage therapy against gut-derived sepsis caused by Pseudomonas aeruginosa in mice. Antimicrob. Agents Chemother. 2007, 51, 446-452. [CrossRef]

85. Gu, J.; Liu, X.; Li, Y.; Han, W.; Lei, L.; Yang, Y.; Zhao, H.; Gao, Y.; Song, J.; Lu, R.; et al. A method for generation bacteriophage cocktail with great therapeutic potential. PLoS ONE 2012, 7, 1-8. [CrossRef]

86. Yen, M.; Cairns, L.S.; Camilli, A. A cocktail of three virulent bacteriobacteriophages prevents Vibrio cholerae infection in animal models. Nat. Commun. 2017, 8, 1-7. [CrossRef] [PubMed]

87. D'Herelle, F. On an invisible microbe antagonistic toward dysenteric bacilli: Brief note by Mr. F. D'Herelle, presented by Mr. Roux. 1917. Res. Microbiol. 2007, 158, 553-554.

88. Larkum, N.W. Bacteriophagy in urinary infection part I. The incidence of bacteriobacteriophage and of bacillus coli susceptible to dissolution by the bacteriobacteriophage in urines. Presentation of cases of renal infection in which bacteriobacteriophage was used therapeutically. J. Bacteriol. 1925, 12, 203-223.

89. Larkum, N.W. Bacteriophagy in urinary infection part II. Bacteriophagy in the bladder. J. Bacteriol. 1926, 12, 225-242. [CrossRef] [PubMed]

90. Schultz, I.; Neva, F.A. Relationship between blood clearance and viruria after intravenous injection of mice and rats with bacteriobacteriophage and polioviruses. J. Immunol. 1965, 94, 833-841.

91. Weber-Dabrowska, B.; Dabrowski, M.; Slopek, S. Studies on bacteriobacteriophage penetration in patients subjected to bacteriophage therapy. Arch. Immunol. Ther. Exp. 1987, 35, 563-568.

92. Woźnica, W.M.; Bigos, J.; Łobocka, M.B. Liza komórek bakteryjnych w procesie uwalniania bakteriofagów—Kanoniczne i nowo poznane mechanizmy [Lysis of bacterial cells in the process of bacteriobacteriophage release-canonical and newly discovered mechanisms]. Postepy Hig. Med. Dosw. 2015, 69, 114-126. (In Polish)

93. Foxman, B. Epidemiology of urinary tract infections: Incidence, morbidity, and economic costs. Am. J. Med. 2002, 113, 5S-13S. [CrossRef]

94. Jacobsen, S.M.; Stickler, D.J.; Mobley, H.L.; Shirtliff, M.E. Complicated catheter-associated urinary tract infections due to Escherichia coli and Proteus mirabilis. Clin. Microbiol. Rev. 2008, 21, 26-59. [CrossRef]

95. Carlet, J.; Collignon, P.; Goldmann, D.; Goossens, H.; Gyssens, I.C.; Harbarth, S.; Jarlier, V.; Levy, S.B.; N’Doye, B.; Pittet, D.; et al Society's failure to protect a precious resource: Antibiotics. Lancet 2011, 378, 369-371. [CrossRef]

96. Verbeken, G.; Huys, I.; Pirnay, J.P.; Jennes, S.; Chanishvili, N.; Scheres, J.; Górski, A.; De Vos, D.; Ceulemans, C. Taking bacteriobacteriophage therapy seriously: A moral argument. Biomed. Res. Int. 2014, 2014, 621316. [CrossRef] [PubMed]

97. Ujmajuridze, A.; Chanishvili, N.; Goderdzishvili, M.; Leitner, L.; Mehnert, U.; Chkhotua, A.; Kessler, T.M.; Sybesma, W. Adapted Bacteriobacteriophages for Treating Urinary Tract Infections. Front. Microbiol. 2018, 9, 1832. [CrossRef] [PubMed]

98. Furfaro, L.L.; Payne, M.S.; Chang, B.J. Bacteriobacteriophage Therapy: Clinical Trials and Regulatory Hurdles. Front. Cell Infect. Microbiol. 2018, 8, 376. [CrossRef] [PubMed]

99. Abdelkader, K.; Gerstmans, H.; Saafan, A.; Dishisha, T.; Briers, Y. The Preclinical and Clinical Progress of Bacteriobacteriophages and Their Lytic Enzymes: The Parts are Easier than the Whole. Viruses 2019, 11, 96. [CrossRef] [PubMed]

100. Zalewska-Piątek, B.; Piatek, R. Bacteriophage Therapy as a Novel Strategy in the Treatment of Urinary Tract Infections Caused by E. coli.. Antibiotics 2020, 9, 304. [CrossRef]

101. Oechslin, F. Resistance Development to Bacteriobacteriophages Occurring during Bacteriobacteriophage Therapy. Viruses 2018, 10, 351. [CrossRef]

102. Hyman, P. Bacteriophages for Bacteriophage Therapy: Isolation, Characterization, and Host Range Breadth. Pharmaceuticals 2019, 12, 35. [CrossRef] [PubMed]

103. Batinovic, S.; Wassef, F.; Knowler, S.A.; Rice, D.; Stanton, C.R.; Rose, J.; Tucci, J.; Nittami, T.; Vinh, A.; Drummond, G.R.; et al. Bacteriobacteriophages in Natural and Artificial Environments. Pathogens 2019, 8, 100. [CrossRef] [PubMed]

104. Nilsson, A.S. Pharmacological limitations of bacteriophage therapy. Ups. J. Med. Sci. 2019, 124, 218-227. [CrossRef]

105. Schmerer, M.; Molineux, I.J.; Bull, J.J. Synergy as a rationale for bacteriophage therapy using bacteriophage cocktails. Peer J. 2014, 2, e590. [CrossRef]

106. Nishikawa, H.; Yasuda, M.; Uchiyama, J.; Rashel, M.; Maeda, Y.; Takemura, I.; Sugihara, S.; Ujihara, T.; Shimizu, Y.; Shuin, T.; et al. T-even-related bacteriobacteriophages as candidates for treatment of Escherichia coli UTIs. Arch. Virol. 2008, 153, 507-515. [CrossRef] 
107. Tóthová, L.; Celec, P.; Bábíčková, J.; Gajdošová, J.; Al-Alami, H.; Kamodyova, N.; Drahovská, H.; Liptáková, A.; Turňa, J.; Hodosy, J. Bacteriophage therapy of Cronobacter-induced urinary tract infection in mice. Med. Sci. Monit. 2011, 17, BR173-BR178. [CrossRef]

108. Sybesma, W.; Zbinden, R.; Chanishvili, N.; Kutateladze, M.; Chkhotua, A.; Ujmajuridze, A.; Mehnert, U.; Kessler, T.M. Bacteriobacteriophages as Potential Treatment for Urinary Tract Infections. Front. Microbiol. 2016, 7, 465. [CrossRef]

109. Soto, S.M. Importance of Biofilms in Urinary Tract Infections: New Therapeutic Approaches. Adv. Biol. 2014, 13, 543974. [CrossRef]

110. Djeribi, R.; Bouchloukh, W.; Jouenne, T.; Menaa, B. Characterization of bacterial biofilms formed on urinary catheters. Am. J. Infect. Control 2012, 40, 854-859. [CrossRef] [PubMed]

111. Vukotic, G.; Obradovic, M.; Novovic, K.; Di Luca, M.; Jovcic, B.; Fira, D.; Neve, H.; Kojic, M.; McAuliffe, O. Characterization, Antibiofilm, and Depolymerizing Activity of Two Bacteriophages Active on Carbapenem-Resistant Acinetobacter baumannii. Front. Med. 2020, 7, 426. [CrossRef] [PubMed]

112. Grygorcewicz, B.; Wojciuk, B.; Roszak, M.; Łubowska, N.; Błażejczak, P.; Jursa-Kulesza, J.; Rakoczy, R.; Masiuk, H.; Dołegowska, B. Environmental Bacteriophage-Based Cocktail and Antibiotic Combination Effects on Acinetobacter baumannii Biofilm in a Human Urine Model. Microb. Drug Resist. 2021, 27, 25-35. [CrossRef]

113. Cieślik, M.; Bagińska, N.; Górski, A.; Jończyk-Matysiak, E. Animal Models in the Evaluation of the Effectiveness of Bacteriophage Therapy for Infections Caused by Gram-Negative Bacteria from the ESKAPE Group and the Reliability of Its Use in Humans. Microorganisms 2021, 9, 206. [CrossRef]

114. De Miguel, T.; Rama, J.; Sieiro, C.; Sánchez, S.; Villa, T.G. Bacteriobacteriophages and Lysins as Possible Alternatives to Treat Antibiotic-Resistant Urinary Tract Infections. Antibiotics 2020, 9, 466. [CrossRef] [PubMed]

115. Lood, R.; Winer, B.Y.; Pelzek, A.J.; Diez-Martinez, R.; Thandar, M.; Euler, C.W.; Schuch, R.; Fischetti, V.A. Novel bacteriophage lysin capable of killing the multidrug-resistant gram-negative bacterium Acinetobacter baumannii in a mouse bacteremia model. Antimicrob. Agents Chemother. 2015, 59, 1983-1991. [CrossRef]

116. Leitner, L.; Ujmajuridze, A.; Chanishvili, N.; Goderdzishvili, M.; Chkonia, I.; Rigvava, S.; Chkhotua, A.; Changashvili, G.; McCallin, S.; Schneider, M.P.; et al. Intravesical bacteriobacteriophages for treating UTIs in patients undergoing transurethral resection of the prostate: A randomised, placebo-controlled, double-blind clinical trial. Lancet Infect. Dis. 2020, 16, S1473. [CrossRef]

117. Goodridge, L.D. Designing bacteriophage therapeutics. Curr. Pharm. Biotechnol. 2010, 11, 15-27. [CrossRef]

118. Azeredo, J.; Sutherland, I.W. The use of bacteriophages for the removal of infectious biofilms. Curr. Pharm. Biotechnol. 2008, 9 , 261-266. [CrossRef] [PubMed]

119. Górski, A.; Międzybrodzki, R.; Borysowski, J.; Dabrowska, K.; Wierzbicki, P.; Ohams, M.; Korczak-Kowalska, G.; OlszowskaZaremba, N.; Lusiak-Szelachowska, M.; Klak, M.; et al. Bacteriophage as a modulator of immune responses: Practical implications for bacteriophage therapy. Adv. Virus Res. 2012, 83, 41-71.

120. Rostkowska, O.M.; Międzybrodzki, R.; Miszewska-Szyszkowska, D.; Górski, A.; Durlik, M. Treatment of recurrent urinary tract infections in a 60-year-old kidney transplant recipient. The use of bacteriophage therapy. Transpl. Infect. Dis. 2020, 29 , e13391. [CrossRef]

121. World Health Organization (WHO). 2018. Available online: http://www.who.int/mediacentre/news/releases/2017/bacteriaantibiotics-needed/en (accessed on 14 January 2021).

122. Coelho, J.; Woodford, N.; Turton, J.; Livermore, D.M. Multiresistant Acinetobacter in the UK: How big a threat? J. Hosp. Infect. 2004, 58, 167-169. [CrossRef]

123. Gupta, K. Emerging antibiotic resistance in urinary tract pathogens. Infect. Dis Clin. N. Am. 2003, 17, 243-259. [CrossRef]

124. World Health Organization (WHO). 2014. Available online: http://apps.who.int/iris/bitstream/10665/112642/1/97892415647 48_eng.pdf (accessed on 14 January 2021).

125. Cai, T.; Nesi, G.; Mazzoli, S.; Meacci, F.; Lanzafame, P.; Caciagli, P.; Mereu, L.; Tateo, S.; Malossini, G.; Selli, C.; et al. Asymptomatic bacteriuria treatment is associated with a higher prevalence of antibiotic resistant strains in women with urinary tract infections. Clin. Infect. Dis. 2015, 61, 1655-1661. [CrossRef] [PubMed]

126. Wagenlehner, F.M.; Naber, K.G. Editorial commentary: Treatment of asymptomatic bacteriuria might be harmful. Clin. Infect. Dis. 2015, 61, 1662-1663.

127. Jasim, H.N.; Hafidh, R.R.; Abdulamir, A.S. Formation of therapeutic bacteriophage cocktail and endolysin to highly multi-drug resistant Acinetobacter baumannii: In vitro and in vivo study. Iran. J. Basic Med. Sci. 2018, 21, 1100-1108. [CrossRef] [PubMed]

128. Malik, S.; Sidhu, P.K.; Rana, J.S.; Nehra, K. Managing urinary tract infections through bacteriophage therapy: A novel approach. Folia Microbiol. 2020, 65, 217-231. [CrossRef] [PubMed] 